\title{
KERAGAAN REMATURASI GONAD INDUK TERIPANG PASIR, Holothuria scabra DENGAN PEMBERIAN JENIS PAKAN BERBEDA
}

\author{
Sari Budi Moria Sembiring\#, Ida Komang Wardana, Nyoman Adiasmara Giri, dan Haryanti \\ Balai Besar Riset Budidaya Laut dan Penyuluhan Perikanan
}

(Naskah diterima: 22 M ei 2017; Revisi final: 22 Juli 2017; Disetujui publikasi: 22 Juli 2017)

\begin{abstract}
ABSTRAK
Rematurasi gonad induk teripang pasir Holothuria scabra yang sudah memijah masih banyak masalah, padahal rematurasi diperlukan untuk keberlanjutan pemijahan dan penyediaan benih. Tujuan penelitian adalah memperoleh jenis pakan yang dapat mempercepat proses rematurasi gonad terhadap induk alam yang sudah dipijahkan sehingga dapat memenuhi kebutuhan untuk pembenihan teripang di hatcheri, serta mengetahui performa benih yang dihasilkan secara fenotipe dan genotipe. Penelitian rematurasi gonad dengan pemberian pakan berbeda telah dilakukan di Balai Besar Penelitian dan Pengembangan Budidaya Laut, Gondol. Penelitian dilakukan dengan metode eksperimental secara rancangan acak lengkap dengan perlakuan perbedaan jenis pakan, yaitu: A) Ulva sp. dan bentos; B) Gracilaria sp. dan bentos, dan C) bentos saja. Dosis pemberian pakan sebanyak 4\%dari bobot badan dengan frekuensi pemberian 1 kali/hari. Setiap perlakuan terdiri atas tiga ulangan. Jumlah induk setiap ulangan sebanyak tiga ekor dengan ukuran panjang dan bobot $13,08 \pm 2,04 \mathrm{~cm}$ dan $182,75 \pm 47,74 \mathrm{~g}$. Benih yang dihasilkan sebelum induk dirematurasi dan setelah rematurasi diamati performa fenotipe dan genotipenya. Analisis genotipe menggunakan metode mikrosatellit dengan empat lokus (Hsc-11; Hsc-28; Hsc-49; dan Hsc-59). Parameter yang diamati meliputi frekuensi pemijahan induk teripang, tingkat kematangan gonad, indeks gonadosomatik, fekunditas, diameter telur, pertumbuhan benih F-1 sebelum dan sesudah rematurasi, serta performa genotipe benih tersebut. Data indeks gonad somatik dan diameter telur dianalisis dengan ANOVA, sedangkan data pertumbuhan, pemijahan, dan fekunditas disajikan dalam bentuk tabel dan grafik. Hasil penelitian menunjukkan bahwa semua perlakuan dapat mempercepat rematurasi gonad dan induk teripang memijah setelah dua bulan pemeliharaan. Jenis pakan bentos menghasilkan indeks gonadosomatik dan diameter telur lebih baik dibandingkan dengan perlakuan pakan lainnya $(P<0,05)$. Keragaman genetik benih dari induk sebelum rematurasi $(0,719)$ berbeda nyata $(P<0,05)$ dengan sesudah rematurasi $(0,634)$; sedangkan secara fenotipe, pertumbuhan panjang, dan bobot benih hingga umur 150 hari tidak berbeda $(P>0,05)$.
\end{abstract}

KATA KUNCl: rematurasi; gonad; teripang pasir; pakan

ABSTRACT: Performance of gonad rematuration of sea cucumber Holothuria scabra broodstock fed with different feed ingredients. By: Sari Budi Moria Sembiring, Ida Komang Wardana, Nyoman Adiasmara Giri, and Haryanti

Successful rate of gonad re-maturation of sea cucumber, $\mathrm{H}$. scabra broodstock after spawning still faces some problems presumably due to lack of essential nutrients to support the process. However, re-maturation is vitally important to speed up the fingerling production. The aim of the research was to determine the best feed composition able to induce gonad re-maturation of sea cucumber natural broodstock which had been previously spawned. In addition, this research was also aimed to study the finger ling genetic performance, both phenotypically and genetically. The research on gonad re-maturation was carried out using different feeds at the Institute for Mariculture Research and Development, Gondol. The research was designed in a completely randomized design with three different feed compositions as treatments: A) Ulva sp. and benthos; B) Gracilaria sp. and benthos, and C) only benthos. The amount of given feed was $4 \%$ of the total biomass and once daily. Each treatment has three replicates. The number of broodstock in each replicate was three individuals with the averages of total length and body weight were $13.08 \pm 2.04 \mathrm{~cm}$ and $182.75 \pm 47.74$ $\mathrm{g}$, respectively. Finger lings produced from natural maturation and re-maturation broodstock were phenotypically and

\footnotetext{
\# Korespondensi: Balai Besar Riset Budidaya Laut dan

Penyuluhan Perikanan. Jl. Br. Gondol Kec. Gerokgak Kab.

Buleleng, Po. Box 140, Singaraja 81155, Bali, Indonesia.

Tel. + (0362) 92278

E-mail: moriasembiring@yahoo.co.id
} 


\begin{abstract}
genetically analyzed. Microsatellite method was used for the genetic analysis of four loci (Hsc-11; Hsc-28; Hsc-49; and Hsc-59). The parameters measured were gonad maturity level, gonadosomatic index, spawning frequency, fecundity, eggs diameter, phenotypic, and genetic performance of F-1 fingerlings produced from both natural maturation and rematuration broodstock and compared to each other. Data on gonadosomatic index and eggs diameter werestatistically analyzed using Anova-test, while growth rate, spawning, and fecundity were descriptively compared using tables and figures. The results showed that all feed treatments were able to induce gonad re-maturation and all sea cucumber broodstock re-spawned after two months. Benthos feed had a significant effect in increasing gonad somatic index and eggs diameter compared to the other feed treatments $(P<0.05)$. Genetic variance of $F-1$ fingerlings produced from the natural maturation broodstock $(0.719)$ was significantly different $(P<0.05)$ compared to the fingerlings produced from the re-maturated broodstock (0.634). However, phenotypically, the growth of length and weight after 150 days old fingerling was not significantly different $(P>0.05)$ between the two fingerling generations.
\end{abstract}

\title{
KEYWORDS: rematuration; gonad; sea cuumber; feed
}

\section{PENDAHULUAN}

Teripang adalah organisme laut yang sangat diminati oleh negara-negara tertentu seperti Jepang, Cina, dan Korea; yang dikonsumsi dalam bentuk olahan segar, dingin, beku, dan kering. Selain dikonsumsi sebagai makanan (Chen, 2005); di Cina, teripang juga dimanfaatkan sebagai bahan obat-obatan tradisional (Zhang et al., 2012). Hal ini menyebabkan eksploitasi teripang meningkat dari tahun ke tahun, bahkan menyebabkan over-fishing di beberapa daerah di kawasan Indo-Pasifik (Purcell et al., 2013; Robinson, 2013).

Mengantisipasi over-fishing teripang di Indonesia, pada tahun 2015 Balai Besar Penelitian dan Pengembangan Budidaya Laut Gondol mulai merintis kembali pengembangan teknologi pembenihan teripang pasir. Kegiatan pembenihan teripang pasir masih memanfaatkan induk hasil tangkapan dari alam. Saat ini ketersediaan induk dari alam mulai terbatas sehingga dapat menghambat proses produksi benih. Menurut Jufri et al. (1994) (unpublish) dalam Moria \& Sugama (2001), regenerasi organ dalam teripang telah terbentuk sempurna pada hari ke-30 setelah pengosongan organ dalam dan hari ke-40 gonad mulai berkembang. Di alam, teripang memanfaatkan makanan dari partikel substrat yang ada di dasar air. Jenis makanan teripang terdiri atas organismeorganisme kecil seperti: detritus, protozoa, diatom, alga, kopepoda, ostrakoda, dan rumput laut. Di samping itu, juga foraminifera, radiolarian, dan partikel-partikel pasir atau hancuran karang (Bakus, 1970; Hyman, 1965). Menurut Widodo (1984), pakan teripang di al am sebanyak 80\%merupakan partikel pasir dan $20 \%$ protein dari organisme kecil.

Proses pematangan gonad teripang secara buatan pernah dilakukan, namun belum berhasil seperti pada hewan bintang laut (star fish) dan bulu babi (sea urchin). Hasil penelitian Maruyama (1980) dan Chen et al. (1991) penggunaan 2,3-dimercapto-1-propanol (BAL), dithiothreitol (DTT), dan L-cysteine. 1-M ethyladeninedapat menginduksi $28 \% 90 \%$ pematangan gonad pada
Holothuroids (Echinodermata), namun larva yang dihasilkan 100\%abnormal.

Salah satu faktor yang menentukan keberhasilan perbenihan adalah potensi genetik yang dimiliki oleh populasi yang dibenihkan. Interaksi antara variasi genetik dan lingkungan diduga memengaruhi performa fenotipe dari potensi genetik yang baik untuk mendapatkan hasil yang optimal. Apabila potensi genetik didukung oleh lingkungan yang sesuai maka akan terekspresi secara maksimal dan menghasilkan fenotipe yang maksimal pula (Dunham, 2004). Oleh karena itu, pada penelitian ini perlu dilakukan pengamatan fenotipe dan genotipe benih yang dihasilkan dari induk F-0 yang matang gonad alam dan benih dari induk gonad rematurasi. Pada penelitian ini, pengamatan genotipe menggunakan penanda mikrosatelit karena secara optimal dapat memetakan gen dan bertanggung jawab pada kondisi faktor tunggal atau untuk kondisi multi faktor (Quantitative Traits Loci, QTL) (Magoulas, 1998).

Tujuan dari penelitian ini adalah untuk memperoleh jenis pakan yang dapat mempercepat proses rematurasi gonad terhadap induk alam yang sudah dipijahkan sehingga dapat memenuhi kebutuhan untuk pembenihan teripang di hatcheri, serta mengetahui performa benih yang dihasilkan secara fenotipe dan genotipe.

\section{BAHAN DAN METODE}

\section{Hewan Uji}

Induk teripang pasir yang digunakan merupakan hasil tangkapan di alam. Total induk yang digunakan sebanyak 27 ekor dengan ukuran panjang dan bobot masing-masing sebesar $13,08 \pm 2,04 \mathrm{~cm}$ dan 182,75 $\pm 47,74 \mathrm{~g}$. Sebelum diperlakukan, induk teripang tersebut terlebih dahulu dipijahkan dengan sistem kejut suhu (Battaglene et al., 2002).

Wadah penelitian yaitu bak beton ukuran $200 \mathrm{~cm} x$ $150 \mathrm{~cm} \times 70 \mathrm{~cm}$ sebanyak tiga buah dan masing-masing bak disekat menjadi tiga bagian sehingga total unit 
perlakuan sebanyak sembilan buah dengan sistem pemeliharaan menggunakan substrat pasir (Gambar 1).

\section{Perlakuan}

Perlakuan dalam penelitian ini adalah jenis pakan yang berbeda, yaitu: perlakuan A: Ulva sp. dan bentos (1:1); perlakuan B: Gracilaria sp. dan bentos (1:1); dan perlakuan C: bentos. Setiap perlakuan terdiri atas tiga ulangan. Hasil analisis proksimat dari jenis pakan uji yang berbeda tertera pada Tabel 1 . Pada setiap perlakuan jumlah induk yang digunakan sebanyak sembilan individu.

Frekuensi pemberian pakan satu kali per hari (sore hari) dengan dosis 4\%bobot badan (Wang et al., 2009). Penelitian berlangsung selama delapan bulan dan setelah dua bulan pemeliharaan, induk dipijahkan.

\section{Parameter yang Diamati}

Selama penelitian dilakukan pengamatan terhadap performa fenotipe: pertumbuhan panjang dan bobot induk teripang pasir, frekuensi pemijahan, tingkat kematangan gonad, mutu gonad dan telur (indeks gonadosomatik, fekunditas, diameter telur), serta pertumbuhan benih $\mathrm{F}-1$.

\section{Tingkat Kematangan Gonad}

Penentuan tingkat kematangan gonad (TKG) berdasarkan klasifikasi Morgan (2000); Shiell \& Uthicke (2005); dan Navarro et al. (2012). Tingkat kematangan gonad diklasifikasikan berdasarkan warna gonad dan diameter oosit (Tabel 2). Pada akhir penelitian, semua induk dibedah untuk mengetahui jenis kelamin dan tingkat kematangan gonadnya dengan metode histologi. Analisis histologi gonad dilakukan berdasarkan metode Luna (1968) dan Panigoro et al. (2007) dengan pewarnaan hematoxylen dan eosin.

\section{Indeks Gonado Somatik}

Indeks gonado somatik (GSI) dihitung dengan cara membandingkan bobot gonad dengan bobot badan, dan dikalikan 100 dengan satuan persen (\%).

\section{Fekunditas}

Fekunditas dihitung dengan metode gravimetri yaitu dengan cara menimbang telur sebanyak $1 \mathrm{~g}$ kemudian dihitung jumlah telur tersebut. Hasil perhitungan telur dalam jumlah $1 \mathrm{~g}$ dikalikan dengan bobot gonad keseluruhan (Effendie, 1979).
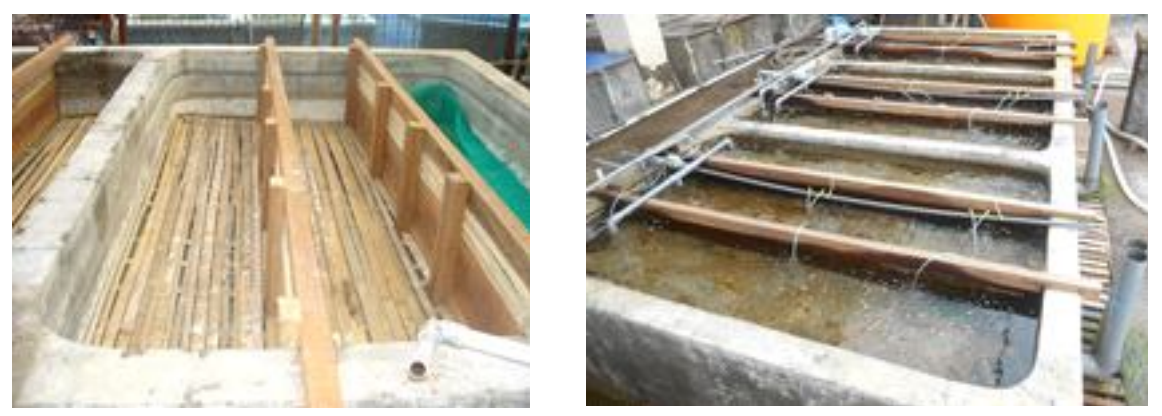

Gambar 1. Bak beton yang digunakan untuk rematurasi induk teripang pasir, H. scabra dengam pemberian jenis pakan berbeda.

Figure 1. Concrete tanks used in the re-maturation of sea sucumber $\mathbf{H}$. scabra broodstock fed with different feeds.

Tabel 1. Komposisi proksimat pakan uji

Table 1. Proximate composition of the experimental feeds

\begin{tabular}{lccc}
\hline \multicolumn{1}{c}{$\begin{array}{c}\text { Parameter } \\
\text { Parameters }\end{array}$} & $\begin{array}{c}\text { Ulva sp. dan bentos } \\
\text { Ulva }\end{array}$ & $\begin{array}{c}\text { Gracilaria sp. dan benthos } \\
\text { Gracilaria sp. and benthos }\end{array}$ & $\begin{array}{c}\text { Bentos } \\
\text { Benthos }\end{array}$ \\
\hline Kadar Abu (Ash) (\%DM) & 51.05 & 57.59 & 68.01 \\
Lemak (Lipid) (\%DM) & 3.33 & 4.63 & 3.75 \\
Protein (\%DM) & 11.13 & 13.61 & 12.59 \\
Serat (Fiber) (\%DM) & 11.79 & 11.60 & 11.89 \\
Bahan ekstrak tanpa nitrogen & 22.7 & 12.57 & 3.76 \\
Nitrogen free extract (\%DM) & & & \\
\hline
\end{tabular}


Tabel 2. Tingkat kematangan gonad diklasifikasikan berdasarkan warna gonad dan diameter oosit Table 2. Classification of gonad maturity index based on gonad color and oocyt diameter

\begin{tabular}{ccc}
\hline $\begin{array}{c}\text { Tingkat } \\
\text { kematangan } \\
\text { gonad } \\
\text { Gonad } \\
\text { maturity index }\end{array}$ & Jantan (Male) & Betina (Female) \\
\hline I & warna gonad putih jernih & warna gonad kuning cerah dan ukuran \\
& Gonad color is transparent & diameter oosit 0-50 mikron (Gambar 2c) \\
& Gonad color is bright yellow and oocyt \\
diameter 0-50 micro meter (Figure 2c)
\end{tabular}

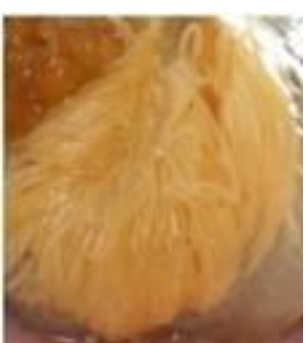

a

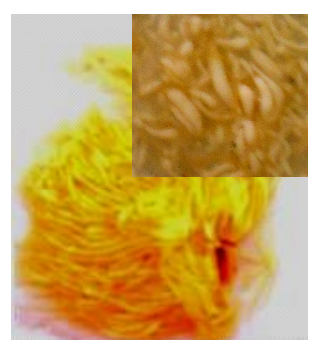

b

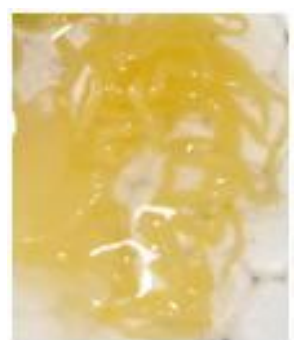

C

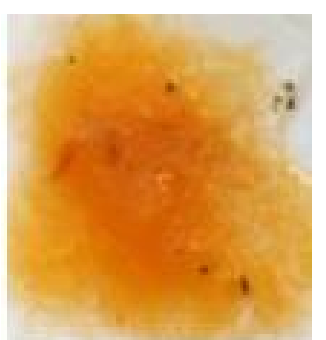

d

Gambar 2. Gonad jantan dan betina induk teripang pasir, Holothuria scabra ( $a=$ gonad jantan tingkat kematangan III; $b=$ gonad jantan tingkat kematangan IV; $c=$ gonad betina tingkat kematangan I; dan $d=$ gonad betina tingkat kematangan III).

Figure 2. Gonad maturity of male and female broodstock of sea cucumber, Holothuria scabra ( $a=$ testis at stage III; $b=$ testis at stage IV; $c=$ oocyt at stage I; and $d=00$ cyt at stage III). 


\section{Performa Benih}

Performa genotipe benih F-1 hasil pemijahan awal sebelum induk dirematurasi dibandingkan dengan benih F-1 dari hasil induk rematurasi juga diamati. Performa genotipe benih dianalisis menggunakan metode mikrosatelit dengan empat lokus, yaitu Hsc11; Hsc-28; Hsc-49; dan Hsc-59 (Sembiring et al., 2016).

\section{Analisa Data}

Data yang diperoleh disajikan dalam bentuk tabel dan grafik meliputi pertumbuhan; pemijahan, dan fekunditas telur, sedangkan untuk mengetahui pengaruh jenis pakan terhadap parameter rematurasi gonad, maka data GSI, dan diameter telur dianalisis dengan ANOVA pada taraf nyata $5 \%$ Jika hasil menunjukkan adanya pengaruh yang nyata maka dilakukan uji lanjut menggunakan Tukey test. Analisis statistik menggunakan software $\mathrm{R}$ version 3.3.2, sedangkan untuk analisis genotipe mikrosatelit menggunakan software Arlequin (Excoffier \& Lischer, 2010).

\section{HASIL DAN BAHASAN}

\section{Pertumbuhan Induk Teripang Pasir}

Pola pertumbuhan induk teripang pasir berdasarkan ukuran panjang total dan bobot badan disajikan pada Gambar 3 dan 4. Dari Gambar 3 dan 4, terlihat bahwa pola pertumbuhan teripang pasir untuk ketiga perlakuan menunjukkan pola yang relatif sama, nampaknya teripang dapat mengonsumsi semua jenis pakan perlakuan yang diberikan. Pertimbangan jenis pakan yang digunakan dalam penelitian ini karena sesuai dengan habitat teripang di alam yaitu pada ekosistem pantai berbatu, karang, berpasir dengan sedikit lumpur, dan banyak ditumbuhi rumput laut atau sea grass (Liu et al., 2010). Pada awal penelitian, bobot badan induk yang diberi pakan sesuai perlakuan mengalami penurunan hingga empat bulan pemeliharaan, hal ini diduga selain beradaptasi terhadap pakan yang diberikan, juga disebabkan karena sebagian besar energi yang diperoleh dari hasil metabolisme tertuju pada perkembangan gonad. Menurut Meunpol et al. (2005), perkembangan gonad akan semakin besar dan matang hingga fase pemijahan. Pada fase tersebut sebagain besar hasil metabolisme digunakan untuk perkembangan gonad.

\section{Tingkat Kematangan Gonad}

Hasil dari pengamatan tingkat kematangan gonad berdasarkan histologi gonad yang dipotong secara melintang dapat dilihat pada Gambar 5.

Berdasarkan pengamatan preparat histologi, terlihat secara jelas bahwa terdapat berbagai ukuran diameter oosit dalam satu potongan melintang gonad. Untuk menentukan TKG yang lebih detail, maka dilakukan penghitungan rasio antar ukuran diameter oosit yang disajikan pada Tabel 3. Pengamatan data histologi menunjukkan bahwa induk teripang pasir cenderung bersifat parsial spawning.

Persentase tingkat kematangan gonad berdasarkan rasio ukuran oosit yang diperoleh dari semua induk betina pada masing-masing perlakuan. Penentuan

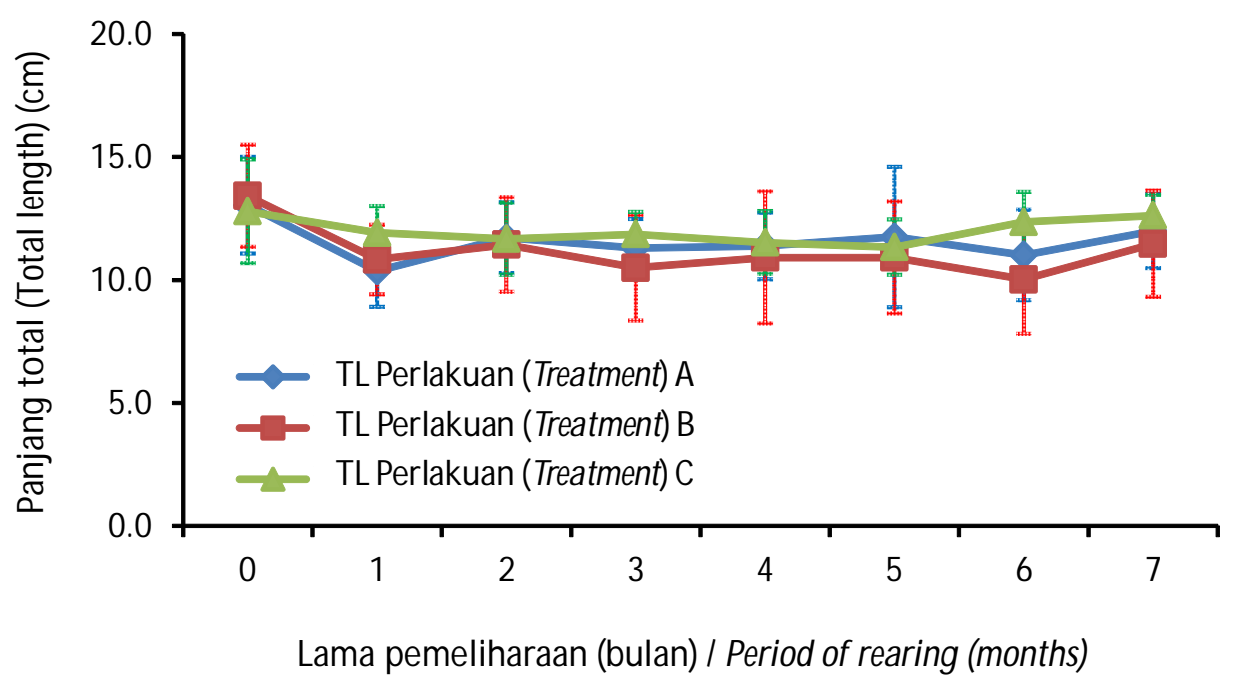

Gambar 3. Panjang total $(\mathrm{cm})$ induk teripang pasir, H. scabra dengan pemberian jenis pakan yang berbeda selama penelitian.

Figure 3. Total length $(\mathrm{cm})$ of broodstock sea cucumber, H. scabra fed with different feeds during experiment. 


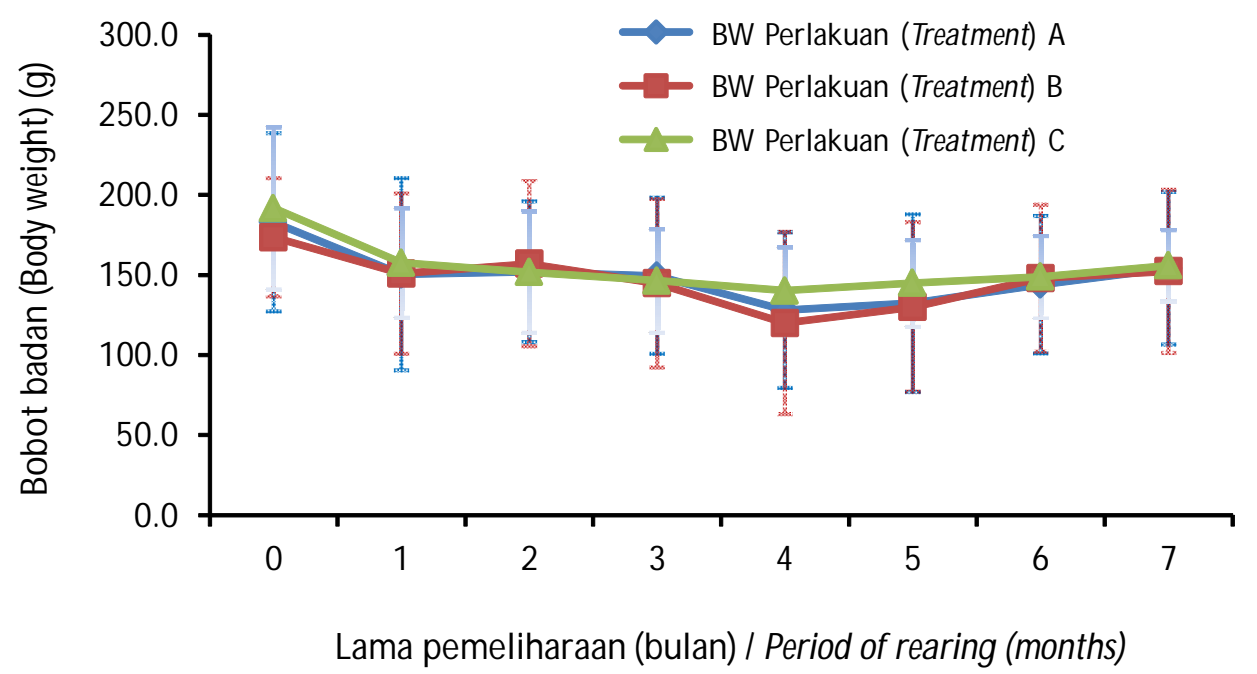

Gambar 4. Bobot badan (g) induk teripang pasir, H. scabra dengan pemberian jenis pakan yang berbeda selama penelitian.

Figure 4. Body weight of broodstock sea cucumber, H. scabra fed with different feeds during the experiment.
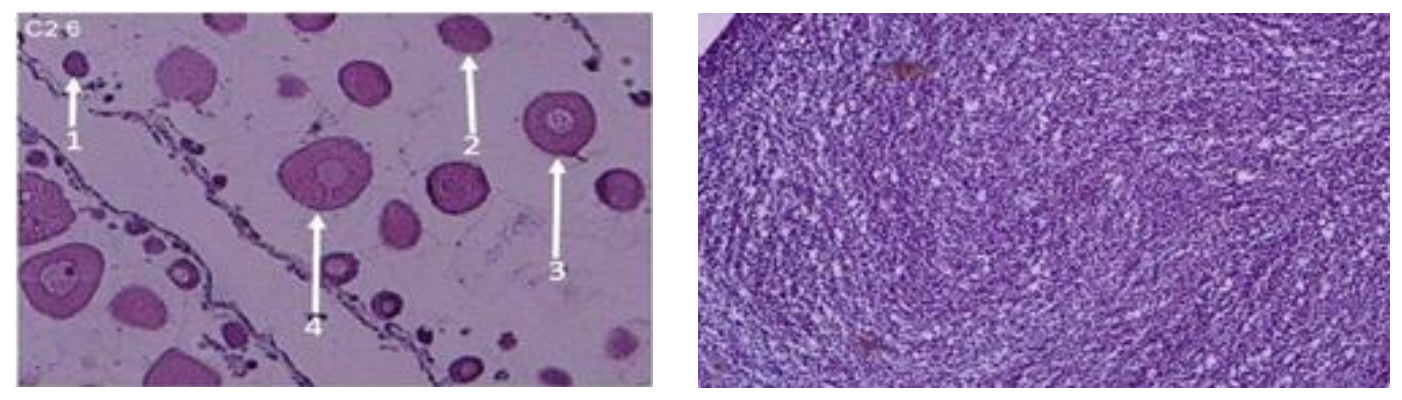

Gambar 5. Profil histologi gonad induk teripang pasir, $H$. scabra $(A=$ gonad betina; $1=$ TKG-I; $2=$ TKG-II; 3; TKG-III; 4= TKG-IV; B= gonad jantan).

Figure 5. Histological section of sea cucumber, $\mathbf{H}$. scabra gonad ( $A=$ female gonad; $1=$ TKG-1; $2=$ TKG-II; $3=$ TKG-III; 4= TKG-IV; $B=$ male gonad).

Tabel 3. Rata-rata tingkat kematangan gonad induk teripang pasir, H. scabra dengan pemberian jenis pakan yang berbeda

Table 3. Average of gonad maturity level of sea cucumber, H. scabra broodstock fed with different feeds

\begin{tabular}{llccc}
\hline & \multicolumn{1}{c}{$\begin{array}{c}\text { Perlakuan } \\
\text { Treatments }\end{array}$} & \multicolumn{2}{c}{$\begin{array}{c}\text { Ratarata tingkat kematangan gonad } \\
\text { Average of gonad maturity level (\%) }\end{array}$} \\
\cline { 3 - 5 } & & II & III & IV \\
\hline A. $\quad \begin{array}{l}\text { Ulva sp. dan bentos } \\
\text { Ulva sp. and benthos }\end{array}$ & 15.83 & 71.67 & 12.50 \\
B. $\quad \begin{array}{l}\text { Gracilaria sp. dan bentos } \\
\text { Gracilaria sp. and benthos }\end{array}$ & 23.33 & 55.00 & 21.67 \\
C. $\quad$ Bentos (Benthos) & 0.84 & 21.67 & 24.43 \\
\hline
\end{tabular}


tingkat kematangan gonad teripang selain berdasarkan ukuran oosit juga berdasarkan warna gonad (Tabel 2 dan Gambar 2). Berdasarkan Tabel 3, terlihat bahwa perlakuan $\mathrm{C}$ memberikan nilai rata-rata TKG-IV yang lebih tinggi dibandingkan dengan perlakuan $\mathrm{A}$ dan $\mathrm{B}$.

\section{Pemijahan}

Perbedaan jenis pakan pada proses rematurasi induk teripang pasir memberikan hasil bahwa induk teripang pada semua perlakuan dapat matang gonad, memijah, dan memproduksi larva. Setelah dua bulan pemeliharaan dengan pemberian jenis pakan yang berbeda ternyata induk teripang pasir mulai ada yang memijah (Tabel 4). Hal ini menunjukkan bahwa perbedaan jenis pakan merupakan faktor yang penting pada proses dan respons terhadap rematurasi induk teripang pasir.

Induk teripang mengalami kematangan gonad dan memijah setelah dua bulan pemeliharaan pada pemberian pakan Gracilaria sp. dan bentos (perlakuan $B$ ), diikuti oleh perlakuan $A$ dan $C$ yang mulai memijah setelah empat bulan pemeliharaan. Selama delapan bulan penelitian, frekuensi pemijahan berkisar antara 2-3 kali dengan jumlah telur bervariasi antara 50.0002.740 .000 dan daya tetas telur $25,0 \% 91,2 \%$ (Tabel 4). Dari setiap pemijahan pada perlakuan A, B, dan C; jumlah induk yang memijah yaitu satu ekor jantan dengan 1-2 ekor induk betina.
Menurut Morgan (2000), faktor utama yang menentukan kecepatan pematangan gonad (rematurasi) teripang adalah pakan yang diberikan selama proses rematurasi tersebut. Hal ini disebabkan karena bahan dasar dalam pembentukan sel telur dan sperma berasal dari hasil metabolisme dari pakan yang diberikan. Di alam, waktu reproduksi ditentukan oleh kemampuan induk teripang dalam mendapatkan makanan yang selanjutnya akan diubah dalam bentuk energi dan melakukan reproduksi (Shi et al., 2015). Selanjutnya dari beberapa hasil penelitian menunjukkan bahwa kombinasi fotoperiode, suhu, dan makanan merupakan faktor yang dapat mendukung proses gametogenesis dan vitelogenesis selama proses reproduksi teripang (Hamel et al., 1993; Zamora \& Jeffs, 2012).

\section{Gonado Somatic Index (GSI) dan Diameter Telur}

Hasil pengamatan terhadap GSI dan diameter telur induk teripang pasir dengan pemberian jenis pakan yang berbeda disajikan pada Tabel 5 . Nilai rata-rata GSI dan diameter telur dari setiap pemberian jenis pakan yang berbeda menghasilkan nilai yang berbeda. Rata-rata GSI pada perlakuan A dan C tidak berbeda nyata $(P>0,05)$, namun berbeda nyata dengan perlakuan $C(P<0,05)$.

Gonado somatic index merupakan evaluasi untuk melihat perubahan yang terjadi pada gonad teripang.

Tabel 4. Frekuensi pemijahan, jumlah telur, daya tetas telur, dan sintasan benih pada rematurasi induk teripang pasir, H. scabra

Table 4. Spawning frequencies, number of eggs, hatching rate, and survival rate of juvenile produced from rematuration of sea cucumber, $\mathbf{H}$. scabra broodstock

\begin{tabular}{ccccc}
\hline $\begin{array}{c}\text { Jumlah pemijahan } \\
\text { Number spawning }\end{array}$ & $\begin{array}{c}\text { Perlakuan } \\
\text { Treatments }\end{array}$ & $\begin{array}{c}\text { Jumlah telur } \\
\text { Number of eggs }\end{array}$ & $\begin{array}{c}\text { Daya tetas } \\
\text { Hatching rate (\%) }\end{array}$ & $\begin{array}{c}\text { Sintasan juvenil } \\
\text { Survival rate of juvenile (d-30) (\%) }\end{array}$ \\
\hline \multirow{2}{*}{ I } & $\begin{array}{c}\text { Ulva sp. dan bentos } \\
\text { Ulva sp. and benthos }\end{array}$ & 760,000 & 78.9 & 0.2 \\
\cline { 2 - 5 } $\begin{array}{c}\text { Gracilaria sp. dan bentos } \\
\text { Gracilaria sp. and benthos }\end{array}$ & $2.740,000$ & 91.2 & 0.37 \\
\cline { 2 - 5 } Bentos (Benthos) & 133,000 & 75.2 & 2.05 \\
\hline II & $\begin{array}{l}\text { Gracilaria sp. dan bentos } \\
\text { Gracilaria sp. and benthos }\end{array}$ & $1,200,000$ & 48.3 & 1.21 \\
\hline $\begin{array}{l}\text { Ulva sp. dan bentos } \\
\text { Ulva sp. and benthos }\end{array}$ & 50,000 & 75.0 & 0.95 \\
\cline { 2 - 5 } & $\begin{array}{l}\text { Gracilaria sp. dan bentos } \\
\text { Gracilaria sp. and benthos }\end{array}$ & 420,000 & 25.0 & 0.4 \\
\cline { 2 - 5 } & Bentos (Benthos) & 2.500 .000 & 52.5 & $\begin{array}{c}\text { Larva mati } \\
\text { umur dua hari } \\
\text { Mortality larva occurred } \\
\text { after two days reared }\end{array}$ \\
\hline
\end{tabular}


Tabel 5. Rata-rata gonado somatic index, dan diameter telur induk teripang pasir, H. scabra dari masing-masing perlakuan

Table 5. The average of gonado somatic index and egg diameter of sea cucumber, H. scabra from each treatment

\begin{tabular}{lcc}
\hline \multicolumn{1}{c}{ Perlakuan (Treatments) } & GSI (\%) & $\begin{array}{c}\text { Diameter telur } \\
\text { Egg diameter }(\mu \mathrm{m})\end{array}$ \\
\hline Ulva sp. dan bentos (Ulva sp. and benthos) & $4.04 \pm 2.20^{\mathrm{ab}}$ & $122.27 \pm 21.34^{\mathrm{a}}$ \\
Gracilaria sp. dan bentos (Gracilaria sp. and benthos) & $2.96 \pm 2.76^{\mathrm{a}}$ & $122.68 \pm 23.06^{\mathrm{a}}$ \\
Bentos (Benthos) & $5.51 \pm 2.79^{\mathrm{b}}$ & $131.95 \pm 17.19^{\mathrm{b}}$ \\
\hline
\end{tabular}

Catatan: Nilai pada kolom diikuti oleh huruf yang sama menunjukkan tidak berbeda nyata $(P>0,05)$

Note: $\quad$ Values in the column with the same letters are not significantly different $(P>0.05)$

Besar atau kecilnya nilai GSI tersebut berkaitan dengan tingkat kematangan gonad (Hendri, 2010). Pada saat proses vitellogenesis berlangsung, granula kuning telur bertambah jumlah dan ukurannya sehingga volume oosit membesar dan akhirnya menyebabkan meningkatnya nilai GSI. Apabila dilihat dari hubungan antara bobot badan dengan GSI (Gambar 6), serta panjang total dengan GSI (Gambar 7), tidak terlihat adanya tren hubungan antara bobot badan, panjang total, dan GSI, namun berdasarkan Gambar 6 dan 7, dapat disimpulkan bahwa nilai GSI yang tinggi menyebar pada induk dengan bobot badan antara 70 $120 \mathrm{~g}$ dengan panjang total $10-14 \mathrm{~cm}$.
Perkembangan gonad yang semakin matang merupakan bagian dari reproduksi teripang sebelum terjadi pemijahan. Selama proses tersebut berlangsung sebagian besar hasil metabolisme dialokasikan untuk pematangan gonad. Menurut Morgan (2001), peran pakan dalam perkembangan gonad penting untuk fungsi endokrin yang normal. Kandungan nutrisi dalam pakan merupakan salah satu faktor penentu dalam menunjang keberhasilan induk mencapai kematangan gonad sampai pada perkembangan oosit, terutama pada awal perkembangan telur.

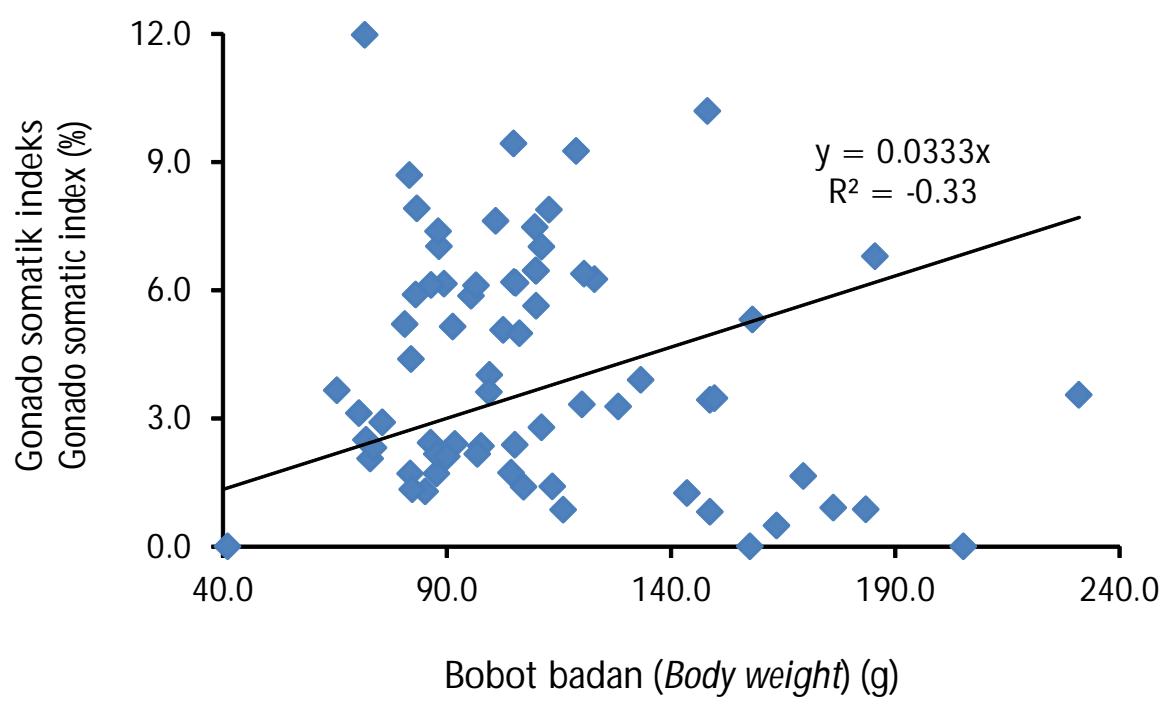

Gambar 6. Hubungan bobot badan (g) induk teripang pasir, H. scabra dengan GSI (\%).

Figure 6. Relation body weight sea cucumber, H. scabra broodstock with GSI (\%). 


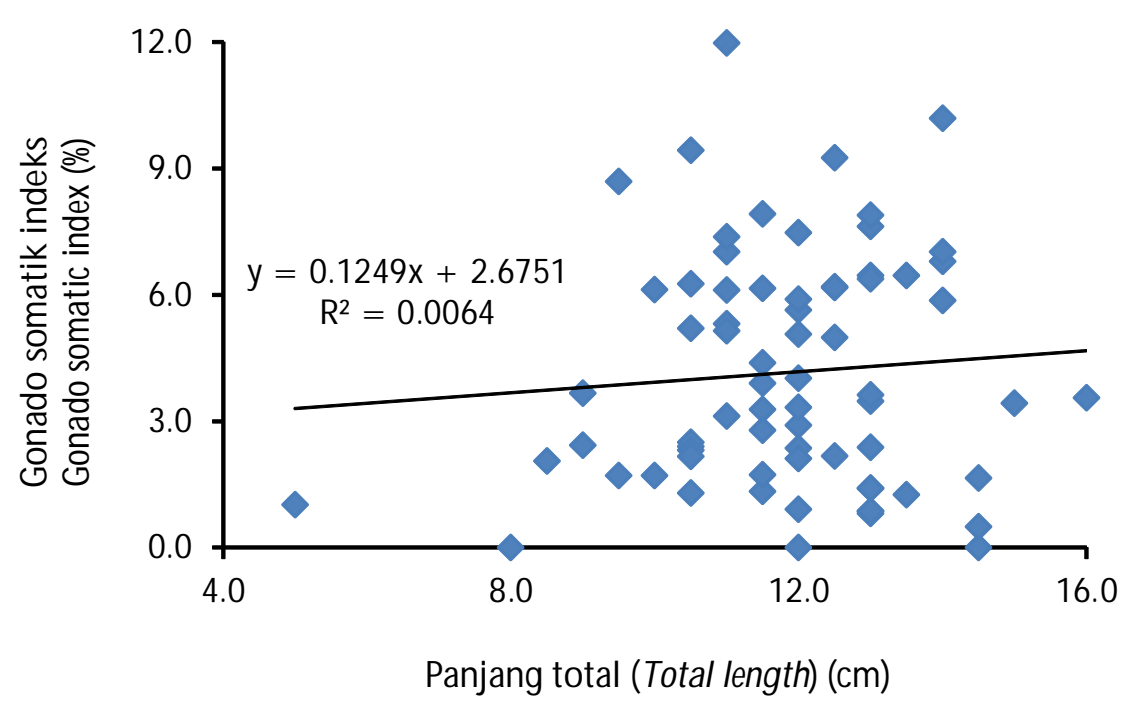

Gambar 7. Hubungan panjang total (cm) dengan GSI (\%) induk teripang pasir, H. scabra.

Figure 7. Relationship between total length and GSI (\%) of sea cucumber, H. scabra broodstock.

Hasil uji lanjut Tukey, dari nilai diameter telur terlihat bahwa pemberian pakan bentos berbeda nyata dengan pakan Gracilaria sp. dan bentos, serta Ulva sp. dan bentos. Perkembangan diameter telur merupakan proses akumulasi vitellogenin yang disintesis hati ke dalam oosit. Tingginya GSI dengan pemberian bentos diikuti dengan tingginya fekunditas dan diameter telur, hal ini terjadi diduga karena kandungan protein dan lemak yang ada di pakan bentos dapat mendukung proses rematurasi gonad teripang pasir (Tabel 1).

Lemak dalam pakan merupakan sumber asam lemak esensial bagi teripang. Lemak selain sebagai sumber energi, juga digunakan untuk struktur sel telur dan perkembangan larva (Carboni et al., 2012). Asam lemak yang berperan dalam proses reproduksi khususnya asam arakidonat (ARA) dan EPA/DHA. Kandungan ARA dalam telur sangat berhubungan dengan fekunditas dan produksi telur (Meunpol et al., 2005). Dilihat dari komposisi asam lemak (ARA; EPA/DHA) Ulva sp.; Gracilaria sp., dan bentos mempunyai nilai yang hampir sama yaitu: 0,3\% kandungan ARA dan 1,35\%2,52\% kandungan EPA/DHA (Giri et al., 2015). Dari hasil analisis proksimat, kadar protein, dan lipid dari ketiga perlakuan menunjukkan nilai yang relatif sama. Oleh karena itu, berdasarkan nilai nutrisi dari setiap pakan yang diberikan dapat diketahui bahwa pada saat proses rematurasi gonad dan pembentukan butir-butir telur, kandungan nutrisi bentos merupakan yang terbaik.

\section{Fekunditas}

Rata-rata fekunditas telur tertinggi secara berurutan yaitu pemberian pakan bentos dengan nilai rata-rata 1.320.940,6 \pm 1.285.702,6; Gracilaria sp. + bentos dengan nilai rata-rata 831.613,4 $\pm 779.863,9$; dan Ulva sp. + bentos dengan nilai rata-rata 808.120,7 \pm 945.074,2 (Gambar 8).

Semakin tinggi tingkat kematangan gonad (TKG), maka semakin besar nilai fekunditasnya. Peningkatan fekunditas dipengaruhi oleh kualitas induk betina dan nutrien pakan, serta efisiensi pemanfaatannya. Jika kualitas pakan yang diberikan kurang bermutu, maka akan terjadi reabsorpsi dan menyebabkan fekunditas berkurang, serta pematangan telur terhambat. Hamel \& Mercier (1996) menyatakan proses gametogenesis induk teripang di alam selain dipengaruhi oleh faktor pakan yang tersedia, juga faktor lingkungan khususnya suhu dan fotoperiode yang dapat mempercepat pematangan oosit.

Kandungan nutrisi dalam pakan teripang merupakan salah satu faktor penentu dalam menunjang keberhasilan induk mencapai kematangan gonad sampai kepada perkembangan oosit, terutama pada awal perkembangan telur. Hasil analisis proksimat (Tabel 1), menunjukkan bahwa pakan semua perlakuan mempunyai kadar lemak yang relatif rendah, kadar serat dan protein mempunyai nilai yang sama, 


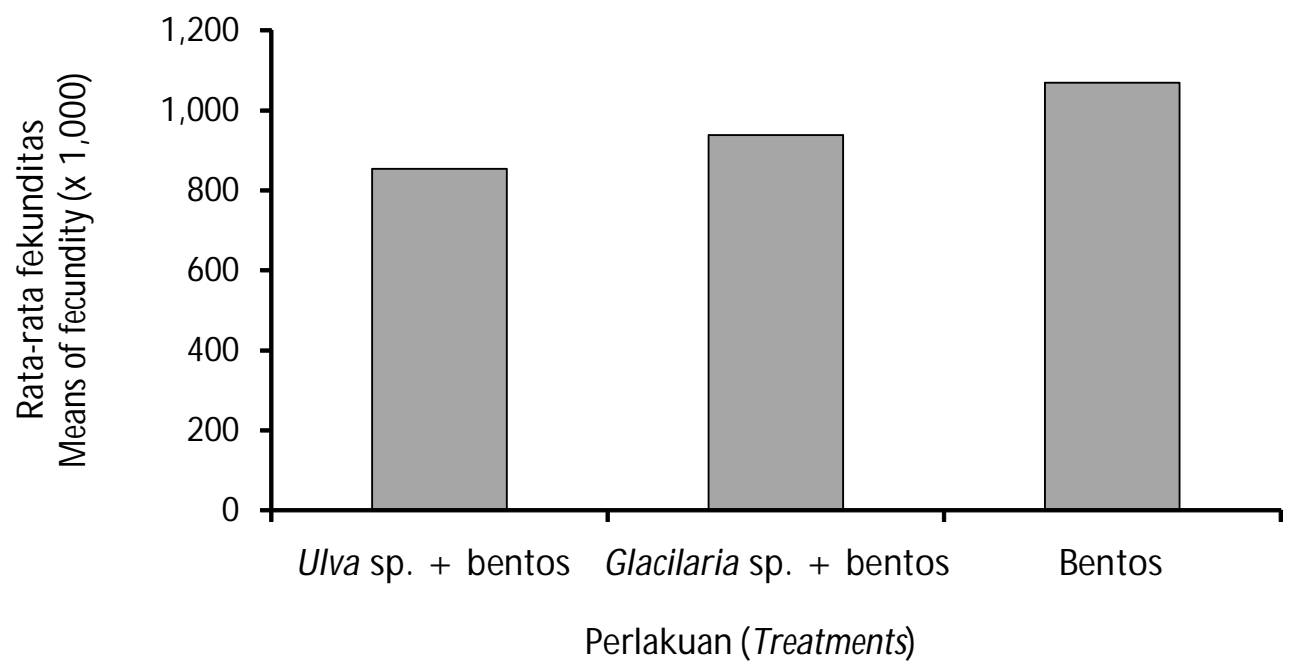

Gambar 8. Rata-rata fekunditas induk teripang pasir, H. scabra.

Figure 8. Means of fecundity of sea cucumber broodstock, H. scabra.

sedangkan kadar abu, pada perlakuan bentos mempunyai nilai yang tinggi dibandingkan dengan Ulva sp. dan bentos, serta pakan Gracilaria sp. dan bentos. Pada proses rematurasi gonad teripang dengan pemberian pakan sesuai perlakuan menunjukkan bahwa dengan pemberian pakan bentos saja, ternyata nilai rata-rata $T K G, G S I$, dan diameter telur lebih tinggi dibandingkan dengan kedua perlakuan lainnya. Hal ini menunjukkan bahwa kandungan lemak dan protein yang terdapat pada pakan bentos sudah mendukung untuk proses rematurasi gonad induk teripang pasir. Hasil penelitian Moria \& Sugama (2001), pada pemeliharaan juvenil hingga benih teripang pasir dengan pemberian pakan pada dosis protein yang berbeda, ternyata diperoleh sintasan yang tinggi pada pemberian pakan dengan dosis protein $7 \%$ bila dibandingkan dengan pemberian pakan dosis protein $14 \% 21 \%$ dan $28 \%$ Selanjutnya dari hasil analisis proksimat pakan uji, ternyata kandungan protein berkisar antara $11 \% 13 \%$ dan kandungan protein sebesar itu masih dapat mendukung untuk proses rematurasi gonad teripang pasir. Menurut Duy (2010), teripang mempunyai kemampuan memanfaatkan makanan dengan kadar protein yang rendah seperti detritus dan rumput laut, juga dapat memanfaatkan bakteri pembusuk yang terdapat pada bahan organik sebagai makanannya.

\section{Variasi Genetik Benih}

Hasil analisis dari ukuran alel yang muncul dapat menggambarkan keragaman genetik dari benih teripang pasir (Tabel 6). Rerata kelimpahan alel, keragaman genetik secara berurutan pada benih dari populasi induk alam dengan pemijahan awal adalah 6,50;
0,719 dan populasi induk alam setelah rematurasi gonad dan terjadi pemijahan: 5,50; 0,634. Dari perhitungan ANOVA dan F-statistik menggunakan software Arlequin, ternyata nilai He pada populasi benih awal berbeda nyata terhadap populasi pemijahan setelah rematurasi $(P<0,05)$. Hal ini disebabkan karena pengaruh dari breeding yang menyebabkan penurunan keragaman genetik. Jumlah induk yang matang gonad dari alam sebanyak 27 ekor sebelum dirematurasi terlebih dahulu dipijahkan dalam satu wadah pemijahan. Diperoleh data bahwa jumlah induk betina yang memijah sebanyak tiga ekor dan jantan dua ekor. Sementara jumlah induk yang memijah setelah rematurasi hanya satu ekor jantan dan 1-2 ekor betina, hal ini yang menyebabkan keragaman genotipenya menurun. Karena secara morfologi belum dapat dibedakan antara induk jantan dan betina, sehingga pada penelitian ini dari sembilan individu yang digunakan pada awal penelitian belum diketahui rasio induk jantan dan betina. Pembedahan dilakukan terhadap seluruh induk pada akhir penelitian sehingga diketahui rasio induk jantan dan betina (Tabel 7). Menurut Yanagisawa (1998) dan Cross (1999), pada saat pemijahan diharapkan jumlah induk teripang yang digunakan lebih banyak sehingga dapat menghindari terjadinya bottlenecks.

Secara fenotipe karakterisasi pertumbuhan panjang dan bobot benih hasil pemijahan sebelum dan sesudah perlakuan terlihat pada Gambar 9, di mana rata-rata pertumbuhan benih sampai umur 150 hari dari pemijahan awal sebelum induk dirematurasi dan pemijahan setelah induk dirematurasi dengan perlakuan jenis pakan tidak berbeda nyata baik pada panjang total maupun bobot badan. Di alam, induk 
Tabel 6. Keragaman genetik benih F-1 teripang pasir, H. scabra yang dianalisis dengan empat lokus mikrosatelit

Table 6. Genetic variations of F-1 sea cucumber $\mathbf{H}$. scabra fingerling, analyzed with four locus microsatellite

\begin{tabular}{|c|c|c|c|c|c|}
\hline $\begin{array}{l}\text { Sumber benih } \\
\text { Source of fingerling }\end{array}$ & $\begin{array}{l}\text { Jumlah sampel (ind.) } \\
\text { Number of samples (ind.) }\end{array}$ & $\begin{array}{l}\text { Lokus } \\
\text { Locus }\end{array}$ & $\begin{array}{l}\text { Jumlah alel } \\
\text { Number of allel }\end{array}$ & Ho & $\mathrm{He}$ \\
\hline \multirow{4}{*}{$\begin{array}{l}\text { Benih dari induk matang gonad alam } \\
\text { Fingerling of natural maturation }\end{array}$} & \multirow{4}{*}{10} & Hsc-11 & 7 & 0.900 & 0.831 \\
\hline & & Hsc-28 & 3 & 0.400 & 0.415 \\
\hline & & $\mathrm{Hsc}-49$ & 7 & 0.300 & 0.736 \\
\hline & & Hsc -59 & 9 & 0.800 & 0.894 \\
\hline \multicolumn{2}{|l|}{ Rata-rata (Average) } & & 6.50 & 0.6 & 0.719 \\
\hline \multirow{4}{*}{$\begin{array}{l}\text { Benih dari induk gonad rematurasi } \\
\text { Fingerling of rematuration }\end{array}$} & \multirow{4}{*}{10} & Hsc-11 & 4 & 0.300 & 0.363 \\
\hline & & $\mathrm{Hsc}-28$ & 4 & 0.600 & 0.594 \\
\hline & & $\mathrm{Hsc}-49$ & 7 & 0.400 & 0.742 \\
\hline & & Hsc-59 & 7 & 0.800 & 0.836 \\
\hline \multicolumn{2}{|l|}{ Rata-rata (Average) } & & 5.50 & 0.525 & 0.634 \\
\hline
\end{tabular}

Tabel 7. Perbandingan Jumlah induk jantan dan betina teripang pasir, Holothuria scabra berdasarkan hasil pembedahan pada akhir penelitian

Table 7. Ratio of male and female of sea cucumber, Holothuria scabra broodstock based on dissection at the end of the experiment

\begin{tabular}{lccc}
\hline \multirow{2}{*}{$\begin{array}{c}\text { Perlakuan } \\
\text { Treatments }\end{array}$} & $\begin{array}{c}\text { Ulangan } \\
\text { Replication }\end{array}$ & \multicolumn{2}{c}{$\begin{array}{c}\text { Jumlah induk (ind.) } \\
\text { Number of broodstock (ind.) }\end{array}$} \\
\cline { 3 - 4 } & & Jantan (Male) & Betina (Female) \\
\hline \multirow{2}{*}{ Ulva sp. dan bentos } & A1 & 2 & 1 \\
Ulva sp. and benthos & A2 & 1 & 2 \\
& A3 & 2 & 1 \\
\hline \multirow{2}{*}{ Gracilaria sp. dan bentos } & B1 & 1 & 2 \\
Gracilaria sp. and benthos & B2 & 1 & 1 \\
& B3 & 2 & 1 \\
\hline \multirow{3}{*}{ Bentos (Benthos) } & C1 & 1 & 2 \\
& C2 & 1 & 2 \\
& C3 & 2 & 1 \\
\hline
\end{tabular}

teripang mengonsumsi pakan dengan jenis yang bervariasi sehingga ketersediaan nutrisi untuk pematangan gonad dan reproduksi lebih baik dibandingkan dengan pematangan gonad di bak yang hanya diberi pakan sesuai dengan perlakuan. Selanjutnya, induk hasil tangkapan dari alam setelah dirematurasi dengan kombinasi pakan Ulva sp. dan bentos; Gracilaria sp. dan bentos atau (hanya bentos), ternyata dapat matang gonad dan memijah, serta menghasilkan benih dengan performa yang tidak berbeda secara fenotipe.

\section{KESIMPULAN}

Pemberian pakan Ulva sp. dan bentos; Gracilaria sp. dan bentos; serta bentos saja dapat memacu proses rematurasi gonad induk teripang pasir H.scabra. Pemberian pakan bentos memberikan hasil GSI, fekunditas, dan diameter telur yang terbaik. Keragaan benih teripang hasil pemijahan awal sebelum dan setelah rematurasi gonad secara genotipe berbeda nyata namun rata-rata pertumbuhan panjang dan bobot badan benih adalah sama. 


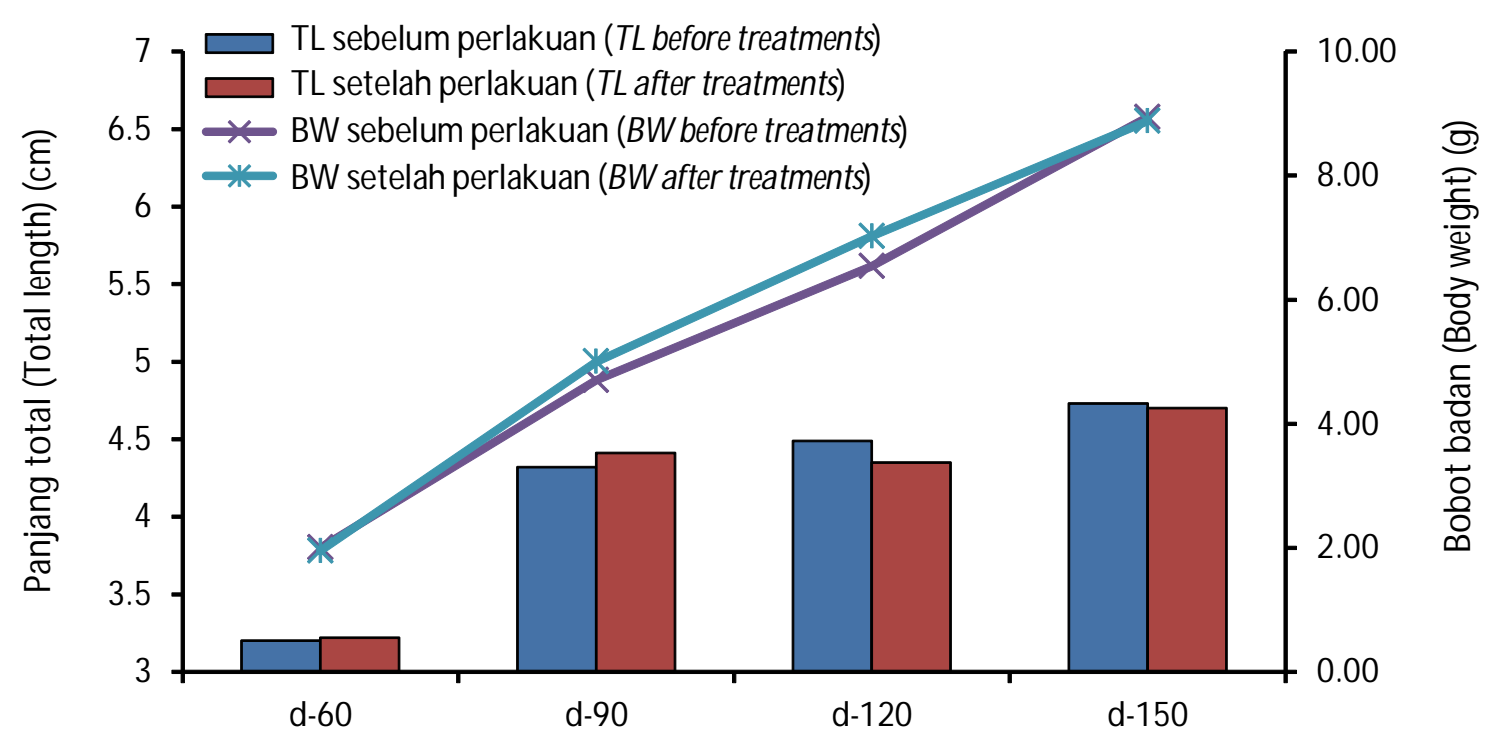

Umur (hari) / Age (days)

Gambar 9. Panjang total (cm) dan bobot badan ( $\mathrm{g}$ ) benih teripang pasir, H. scabra pada pemijahan awal dan pemijahan setelah rematurasi gonad.

Figure 9. Average of total length $(\mathrm{cm})$ and body weight $(\mathrm{g})$ of sea sucumber, $\mathbf{H}$. scabra fingerling at initial spawn and after gonad rematuration.

\section{UCAPAN TERIMA KASIH}

Penelitian ini dilaksanakan dengan pendanaan dari DIPA 2016 Balai Besar Penelitian dan Pengembangan Budidaya Laut Gondol, Kementerian Kelautan dan Perikanan. Penulis juga mengucapkan terima kasih pada semua teknisi litkayasa hatcheri teripang, laboratorium bioteknologi dan laboratorium pakannutrisi atas bantuannya dalam pelaksanaan penelitian ini.

\section{DAFTAR ACUAN}

Bakus, G.J. (1970). The biology and ecology of tropical holothurians. London: Academic Press, p. 121139.

Battaglene, S.C., Seymour, J.E., Ramofafia, C., \& Lane, I. (2002). Spawning induction of three tropical sea cucumber (Holothuria scabra, H. fuscogilva and Actinopyga mauritiana). Aquaculture, 207, 29-47.

Carboni, S., Vignier, J., Chiantore, M., Tocher, D.R., $\&$ Migaud, H. (2012). Effect of dietary micro-algae on growth, survival and fatty acid composition of sea urchin (Paracentrotus lividus) throughout larval develo pment. Aquaculture, 324, 250-258.

Chen, C.P., Hsu, H.W., \& Deng, D.C. (1991). Comparison of larval development and growth of the sea cucumber, Actinopyga echinites: ovary-induced ova and DTT-induced ova. Mar. Biol., 109, 453-457.
Chen, J. (2005). Present status and prospect of sea cucumber industry in China. FAO: www.fao.org [20 Agustus 2007].

Cross, T.F. (1999). Genetic considerations in enhancement and ranching of marine and anadromous species. In Howell, B.R., Moksness, E., \& Svasand, T. (Eds.), Stock Enhancement and Sea Ranching. Proceedings of the 1st International Symposium on Stock Enhancement and Sea Ranching, 8 - 11 September 1997. Bergen, Norway. Blackwell, Oxford, Chap. 3, p. 37-48.

Duy, N.D. (2010). Seed production of sand fish (Holothuria scabra) in Vietnam. Aquaculture extension manual 48, Southeast Asian Fisheries Development Center, Aquaculture Department, Philippines, $12 \mathrm{pp}$.

Dunham, R.A. (2004). Aquaculture and fisheries biotechnology: genetic approaches. (2nd Eds.). USA: CABI Publishing Cambridge, 368 pp.

Effendie, M.I. (1979). Metode biologi perikanan. Bogor: Yayasan Dewi Sri, $112 \mathrm{hlm}$.

Excoffierd, L. \& Lischer, H.E. (2010). Arlequin suite ver 3.5: a new series of programs to perform population genetic analysis under Linux and Windows. Mol. Ecol. Resour., 10, 564-567.

Giri, N.A., Marzuqi, M., Astuti, N.W.W., Andriyanto, W., Rusdi, I., \& Andamari, R. (2015). Evaluasi bahan 
baku pakan dan pengembangan pakan buatan untuk budidaya pembesaran abalon (Haliotis squamata). J. Ris. Akuakultur, 10(3), 379-388.

Hamel, J.F., Himmelman, J.H., \& Dufresne, L. (1993). Gametogenesis and spawning of the sea cucumber (Psolus fabricii) (Duben and Koren). Bio. Bull., 184, 125-143.

Hamel, J.F. \& Mercier, A. (1996). Studies on the reproductive biology of the Atlantic sea cucumber (Cucumaria frondosa). SPC Beche-de-mer Information Bulletin \# 8, April 1996. p. 22-33.

Hendri, A. (2010). M anipulasi fotothermal dalam memacu pematangan gonad ikan Senggaringan (Mystus nigriceps). Tesis. Sekolah Pasca Sarjana. Institut Pertanian Bogor. Bogor, $49 \mathrm{hlm}$.

Hyman, L.H. (1965). The invertebrates. The Echinoderms Vo. IV. New York: Mc Graw-Hill Book Company Co. Inc., 763 pp.

Liu, Y., Dong, S., Tian, X., Wang, F., \& Gao, Q. (2010). The effect of different macroalgae on the growth of sea cucumber (Apostichopus japonicas Selenka). Aquaculture Research, 2, 1-5.

Luna, L.G. (1968). Manual of histological staining methods of the armed forces. Institute of Pathology. $3^{\text {rd }}$. ed. Ner York: McGraw-Hill, p. 420-432.

Magoulas, A. (1998). Application of molecular markers to aquaculture and broodstock management with special emphasis on microsatellite DNA. Article available on line, http://om.ciheam.org/ article.php?IDPDF $=98606201$. p. 153-168.

Maruyama, Y.K. (1980). Artificial induction of oocyte maturation and development in the sea cucumbers, Holothuria leucospilota and Holothuria pardalis. Biol. Bull., 158, 339-348.

Meunpol, O., Meejing, P., \& Somkiat, P. (2005). Maturation diet based on fatty acid content for male Penaeus monodon (Fabricius) broodstock. Aquaculture Research, 36, 1216-1225.

Morgan, A.D. (2000). Induction of spawning in the sea cucumber (Holothuria scabra) (Echinodermata: Holothuroidea). Journal of the World Aquaculture Society, 31(2), 186- 194.

Morgan, A.D. (2001). The effect of food availability on early growth, development and survival of the sea cucumber Holothuria scabra Echinodermata: Holothuroidea). SPC Beche-de-mer Information Bulletin, 14, 6-12.

Moria, B.S. \& Sugama, K. (2001). Pemeliharaan larva teripang pasir (Holothuria scabra) dengan manipulasi pakan dan lingkungan. Jurnal Penelitian Perikanan Indonesia, 7(3), 21-27.

Navarro, P.G., Garzia-Sanz, S., \& Tuya, F. (2012). Reproductive biology of the sea cucumber (Holothuria sanctori) (Echinodermata: Holothuroidea). Scientia Marin, 76(4), 741-752.

Panigoro, N., Astuti, I., Bahnan, M., Salfira, P.D.C., \& Wakita, K. (2007). Teknik dasar histology dan atlas dasar histology ikan. Balai Budidaya Air Tawar Jambi dan Japan International Cooperation Agency, $78 \mathrm{pp}$.

Purcell, S.W., Mercier, A., Conad, C., Hamel, J.F., Toral Granda, M.V., Lovatelli, A., \& Uthicke, S. (2013). Sea cucumber fisheries; global analysis of stocks, management measures and drivers of overfishing. Fish Fish, 14(1), 34-59.

Robinson, G. (2013). A bright future for sandfish. World Aquaculture, 44(1), 19-24.

Sembiring, S.B.M., Wardana, I K., \& Haryanti. (2016). Performa benih teripang pasir (Holothuria scabra) dari sumber induk yang berbeda. J. Ris. Akuakultur, 11(2), 147-154.

Shi, C., Dong, S., Wang, F., Gao, Q., \& Tian, X. (2015). Effect of the sizes of mud or sand particles in feed on growth and energy budgets of young sea cucumber (Aposthicopus japonicus). Aquaculture, 440, 6-11.

Shiell, G. \& Uthicke, S. (2005). Reproduction of the commercial sea cucumber (Holothuria whitmaei Holothuroidea: Aspidochirotida) in the Indian and Pacific Ocean regions of Australia. Mar. Biol., 148(5), 973-986.

Yanagisawa, T. (1998). Aspects of the biology and culture of the sea cucumber. In De Silva, S.S. (Ed.), Tropical mariculture. London: Academic Press, $p$. 292-308.

Wang, J., Su, J., Jiang, Y., Zhang, J., \& Liang, Z. (2009). The effects of dietary vitamin $C$ sources and levels on growth in juvenile sea cucumber (Apostichopus japonicus). Marine Science, 33, 56-63 (in Chinese, with English abstract).

Widodo, R. (1984). Studi beberapa aspek biologi dan ekologi teripang (Holothuria sp.) beserta analisa protein di perairan terumbu karang Pulau Pari. Skripsi. Fakultas Perikanan, Institut Pertanian Bogor. Bogor, hlm. 37-48.

Zamora, L.N. \& Jeffs, A.G. (2012). Feeding, metabolism and growth in response to temperature in juveniles of the Australian sea cucumber (Australostichopus mollis). Aquaculture, 358-359, 92-97.

Zhang, Y., Song, S., Song, D., Liang, H., Wang, W., \& Ji, A. (2012). Proliferative effects on neural stem/ progenitor cells of a sulfated polysaccharide purified from the sea cucumber (Stichopus japonicas). J. Biosci. Bioeng., 109(1), 67-72. 